\title{
sciendo
}

DOI 10.2478/sbe-2019-0047

SBE no. 14(3) 2019

\section{READABILITY OF OPERATIONAL RISK DISCLOSURES OF BANKS}

\author{
MOCANU MIHAELA \\ Bucharest University of Economic Studies, Romania
}

GROSE CHRISTOS

International Hellenic University, Greece

KARGIDIS THEODOROS

International Hellenic University, Greece

\begin{abstract}
:
Operational risk has been acknowledged as a major source of material failures in financial firms. Despite the increased concern of financial institutions and their stakeholders on this topic, the literature that deals specifically with the operational risk disclosure in the banking system is scarce. The present research investigates the readability in transparency reports of Romanian banks, and focuses in particular on the operational risk disclosures. The sample consists of 13 commercial banks operating in Romania in 2017. A concise transparency report is characterized by clarity in the expression of concepts, usage of as few words as possible, limited use of technical terms and avoidance of highly generic disclosures. Drawing upon prior research, we expect that banks with lower levels of performance are foggier (i.e. less concise) in order to improve the image resulting from their transparency reports. Additionally, it is expected that the longer an entity has been established, the higher the quality of disclosures, thus the transparency reports of older banks are more concise compared to the recently established banks. Moreover, we posit that larger banks are more likely to provide more readable reports. The research is part of the larger debate related to disclosure and its various impacts on both the recipient and the giver of information. The main contribution is the innovative approach consisting in the textual analysis of transparency risk reports. To the best of our knowledge, we are not aware of any study that examined conciseness in the setting of operational risk disclosure by banks.
\end{abstract}

Key words: Readability, narrative disclosures, banks, operational risks, Romania

\section{Introduction}

Operational risk disclosure is an important part of the transparency debates within the banking industry. Most operational losses attract the attention of the public, although 
financial losses may be relatively small. Sometimes, the reputational impact is much more significant than the direct effect from the loss itself (Sturm, 2013; Țurlea \& Mocanu, 2016). In no other sector are the interdependencies and the potential consequences of the individual corporate collapses as far-reaching and unforeseeable as in the banking sector (Turlea, Mocanu, Radu, 2010; Mocanu \& Stanciu, 2015). Additionally, operational risk is pervasive, complex and dynamic. Unlike market and credit risk, which tend to be in specific areas of business, operational risk is inherent in all business processes. The multifaceted nature of operational losses makes it difficult to define operational risk and in some cases it is hard to draw the line between operational risk and other types of risk (Sturm, 2013). Compared to credit and market risk, the definition of operational risk explicitly takes into account external as well as internal events and therefore, is broader and more complex (Wahlström, 2006).

Given their complex and pervasive nature, as well as their potential reputational impact, operational risks have recently attracted increased attention from academics, professionals, and regulators. The Romanian literature regarding operational risk management (ORM, hereafter) comprises some theoretical studies (Anghelache et al., 2016; Stanciu, 2010), articles focused on the procedural aspects of ORM (e.g. Dănescu \& Muntean, 2008; Socol et al., 2006), as well as a few empirical papers (Herghiligiu, 2013b; Matiș, 2007; Dima 2009). At global level, the major problems addressed by the literature that deals specifically with operational risk management (ORM) in the banking system relate to (1) the appropriateness of different measurement models for the operational risk capital charge; (2) the determinants of ORM disclosure; (3) the quality and quantity of ORM disclosure. Our research contributes to the growing body of literature on operational risk. The objective of our study is to investigate the determinants of conciseness in operational risk reporting by banks in Romania. Conciseness belongs to the disclosure style in transparency reports and can be defined as clarity in the expression of concepts, usage of as few words as possible, limited use of technical terms and avoidance of highly generic disclosures.

Most researchers investigating operational risks have applied an index to assess the extent of disclosure of financial institutions (e.g. Abu El Haija \& Al Hayek 2012, Avram \& Skully 2007, Barakat \& Khaled 2013, Hossain, 2008, Hemrit \& Ben Arab, 2011, Helbok \& Wagner 2006). Other researchers have created event studies (e.g. Barakat et al. 2014, Benaroch et al. 2012, Chernobai et al. 2011, Cummins et al. 2006, Gillet et al. 2010). Another research method is content analysis performed upon operational risk reports (Oliveira et al. 2011, Sundmacher \& Ford 2006). Few studies take a mathematical modeling approach (Ebnöther et al. 2003, Leippold \& Vanini, 2005). Even fewer researchers apply a survey methodology (Janakiraman 2008, Mehra 2011, Ebnöther et al. 2003). Many other papers include only the position of their authors regarding the debates generated around the topic of operational risk management and disclosure (Galloppo \& Rogora 2011, Power 2005). To the best of our knowledge, no other study used textual analysis to bring more insight into the style of operational risk disclosures and its determinants.

Our paper is structured as follows. The first section offers a brief literature review in order to support the development of the research hypotheses. Secondly, we thoroughly 
describe the research design, which is empirical in nature. The third section describes the results, while the last part of the paper draws the conclusions.

\section{Literature Review and Development of Hypotheses}

A concise transparency report is characterized by clarity in the expression of concepts, usage of as few words as possible, limited use of technical terms and avoidance of highly generic disclosures. Melloni et al. (2017) states that the emphasis on conciseness is innovative, having considered prior attempts to enhance the company's quality of narrative disclosures on financial and nonfinancial matters. Conciseness is part of the style of disclosure, understood as syntactical reading ease. In the present paper, we use the notions "conciseness" and "readability" interchangeably.

Previous research suggests there is an influence of the company's size over the quality and quantity of disclosure. Linsley et al. (2006) analyzed the contents of the annual reports of nine banks from the United Kingdom and nine Canadian banks and found that the extent of risk disclosure is positively associated with bank size. By means of a multivariate regression analysis, both Hossain (2008), and Sanchez-Ballesta \& Bernal Llorens (2010) discovered a positive and statistically significant relation between size as explanatory variable and corporate disclosures as dependent variable. This may be explained by the fact that the cost of collecting and disseminating information is lower for larger institutions and thus, these are able to provide greater and/or better disclosure. Moreover, larger banks are more likely to provide more readable reports, since they might be more visible to the larger public. The largest banks are exposed to greater demands from a greater variety of relevant external actors. They may also be in the position to exert a higher degree of influence over the resource environment. To enhance their corporate reputation, they strategically control the legitimation process through disclosure, in order to influence stakeholders' perceptions of themselves (Oliver, 1991).

$H_{1 A}$ Larger banks produce more readable disclosures on operational risks.

In line with the legitimacy theory, a company's public reputation is determined by how much time that company has been operating. Building a reputation requires consistency in behaviour within the company, as well as consistency in disclosure through time. Specific disclosure actions are taken by companies not because such disclosures directly communicate information to stakeholders, but mostly because they may enhance or impair their reputation (Gibbins et al., 1990). As Oliveira et al. (2011) point out, it is expected that the longer an entity has been established, the higher its reputation level may be. In other words, higher levels of disclosure are expected to build and sustain reputation. Hence, we posit that the transparency reports of older banks are more concise compared to the recently established companies.

$H_{1 B}$ Operational risk disclosures of older banks are more readable.

In line with the impression management literature, we argue that the readability in transparency reports related to operational risk issues vary systematically depending on corporate performance. We draw on prior research (Bakar and Ameer, 2011; Cho et al., 
2010; Plumlee et al., 2015; Wang \& Hussainey, 2013) and expect that financial institutions with low levels of performance are more foggy (less concise / less readable) in order to improve the image resulting from their risk reports. On the contrary, managers of highperforming banks have no incentive to deliberately mislead communication.

$H_{1 C}$ Banks with greater financial performance display a higher level of readability in their transparency reports on operational risk matters.

\section{Research design}

The internet represented the major tool for data collection. The main sources of data for this research were the annual reports published on the official websites of the selected banks. Our sample consists of the annual transparency reports of 13 Romanian commercial banks. The reports concern the financial year 2017, which is the most recent year for which the banks' reports have been made available to the Romanian public. This represents $50 \%$ of the population, namely of all commercial banks which operate in Romania. Only those banks that published reports in English were included in the sample, in order to facilitate data collection and analysis through specialized readability software (readable io). Table 1 provides sample demographics distinguishing between different ages, while Table 2 provides sample demographics that ranks selected banks based on their assets for the year 2017.

Table 1. Sample structure by age

\begin{tabular}{lr} 
Age & \\
younger than 20 years & $38.46 \%$ \\
20-40 years & $46.15 \%$ \\
older than 40 years & $15.38 \%$ \\
Total & \multicolumn{1}{c}{$\mathbf{1 0 0 . 0 0} \%$} \\
\multicolumn{1}{c}{ Table 2. Sample structure by size } \\
Assets & $\%$ \\
below 3.000 .000 TEUR & $53.85 \%$ \\
3.000.000 - 6.000.000 TEUR & $7.69 \%$ \\
6.000.000 - 9.000.000 TEUR & $15.38 \%$ \\
9.000.000 - 12.000.000 TEUR & $7.69 \%$ \\
more than 12.000.000 TEUR & $15.38 \%$ \\
Total & $\mathbf{1 0 0 . 0 0 \%}$
\end{tabular}

We performed a multivariate regression analysis for the dependent variables "readability" of transparency reports. Readability was measured by using the Dale-Chall readability formula (Dale and Chall, 1948). This formula developed by Edgar Dale and Jeanne Chall is calculated by counting difficult words in a piece of text, where those words are simply those not found on a list of common words. Those common words are a list of words with which $80 \%$ or more of fourth-grade students are familiar. That word list has been modified over time and the current version of the formula - the New Dale - Chall Readability Formula - uses about 3,000 words in its list. 
In order to investigate the determinants of readability, we considered a set of explanatory variables which characterize the disclosing financial institutions, namely bank's age; total assets and return on equity. The data was extracted from the annual financial reports as at the 31th of December 2017. All variables used and their definitions are presented in Table 3. A proxy for bank's size is the normalized value of total assets. We have taken into consideration the total assets expressed in the local currency (RON) as at year-end 2017, which we afterwards normalized to values ranging from 0 to 1 . Regarding bank's age, we have computed the number of years elapsed since the commencement of the operations until the end of 2017. In order to express bank's profitability, we have chosen the return on equity, which is computed as the division between net income as at $31^{\text {st }}$ of December 2017 and the total equity as at the same year-end.

Table 3 Variables definition and measurement

\begin{tabular}{l|l|l} 
Variable acronym & Variable definition & Variable measurement \\
\hline $\begin{array}{l}\text { Dependent } \\
\text { Dale-Chall }\end{array}$ & Dale-Chall readability formula & $\begin{array}{l}\text { Number of difficult words as defined by } \\
\text { Dale and Chall }\end{array}$ \\
$\begin{array}{l}\text { Independent } \\
\begin{array}{l}\text { Assets_n } \\
\text { Age }\end{array}\end{array}$ & Bank's size & $\begin{array}{l}\text { Total assets expressed in the local } \\
\text { currency and normalized to fit the } \\
\text { interval (0,1) } \\
\text { Number of years since commencement } \\
\text { of operations }\end{array}$ \\
ROE & Bank's profitability & $\begin{array}{l}\text { Return on Equity computed as Net } \\
\text { income divided by Total Equity }\end{array}$
\end{tabular}

\section{Results}

The means, standard deviations, minimum and maximum of the variables are presented in Table 4. All variables, both the dependent, and the independent ones, are continuous. With reference to the number of difficult words, results show that transparency reports contain on average 413 difficult words, with a maximum of 1.033 words and a minimum of merely 66 words. In Table 4, we present the variable "size" proxied by total assets which are transformed through the formula $(x-\min ) /(\max -\mathrm{min})$ to fit the interval $[0,1]$.

\begin{tabular}{c|rrrr}
\multicolumn{5}{c}{ Table 4 Descriptive statistics } \\
& \multicolumn{1}{|c}{ Mean } & Std. dev. & Minimum & Maximum \\
\hline Dale-Chall & 412.92 & 311.46 & 66.00 & 1033.00 \\
Age & 26.08 & 19.46 & 9.00 & 68.00 \\
Assets_n & 0.32 & 0.37 & 0.00 & 1.00 \\
ROE & 0.04 & 0.13 & -0.27 & 0.20
\end{tabular}

The regression model that we have tested has the following form, whereas "DaleChall" is the number of difficult words, according to the understanding of Dale and Chall, 
therefore the higher the value of this variable, the lower the readability: Dale-Chall $=\beta_{0}+\beta_{1} \cdot$ age $+\beta_{2}$ assets_ $n+\beta_{3} \cdot \mathrm{ROE}+\varepsilon_{\mathrm{t}}$

A multivariate linear regression was calculated to predict Dale-Chall number of difficult words based on banks' age, size and financial performance (see Table 5). The regression model was found valid and its parameters were significant $(F(3,9)=33.84, p<0.01$, with an $\mathrm{R}^{2}$ of 0.89 ). The adjusted $\mathrm{R}$-Squared indicates that $89 \%$ of the variation in the Dale-Chall number of difficult words is explained by the dependent variables. The number of difficult words increased with the size of the bank. Age of the financial institution and its return on equity do not seem to influence the readability of reports. Only the size, measured through total assets, was a significant predictor of the Dale-Chall number of difficult words ( $p$-value $<0.01)$. The larger the bank, the higher the number of difficult words, namely the less readable the transparency report.

Table 5 Model on readability of transparency reports Coefficients

$\begin{array}{lrr}\text { Independent variables } & & \\ \text { Assets_n } & 888.56 & (8.47) \quad{ }^{* * *} \\ \text { Age } & -1.1679 & (-0.69) \\ \text { ROE } & -251.2273 & (-0.87) \\ & & \\ \text { Constant } & 166.82 & \\ \mathrm{R}^{2} & 0.89 \\ \mathrm{~F}(3,9) & 33.84 \quad{ }^{* * *} \\ \text { N } & 13 \\ & & \\ { }^{* * *} \text { Statistically significant at 1\% level. } & & \\ \text { T statistics are in brackets. } & \end{array}$

Additionally, we have tested for the assumptions of the regression and following these tests, we have concluded that the analysis is appropriate for the data at hand. Firstly, Table 6 shows that the dependent variables are not correlated, since each value in the table is less than 0.8. Secondly, we performed the abridged White's test and, due to a significance of 0.94 , we could accept the null hypothesis, thus, we could state that the residuals are homoscedastic. Thirdly, following the Shapiro-Wilk test, it results that the test statistic $\mathrm{W}$ is 0.984 , namely higher than the critical threshold of 0.814 for a significance level of 0.01 and 13 observations. Thus, we concluded that the residuals are normally distributed. Lastly, the Durbin-Watson Statistics is 2.012 , which means that the values of the residuals are independent.

Table 6 Correlation analysis

\begin{tabular}{lccc}
\hline & Age & Assets_n & ROE \\
\hline Age & 1.0000 & & \\
Assets_n & 0.4235 & 1.0000 & \\
ROE & 0.3256 & 0.5894 & 1.0000 \\
\hline
\end{tabular}




\section{Discussion and Conclusions}

This research contributes to the larger debate on disclosure quality by analysing the lexical features of operational risk reports and by aiming to understand its most relevant determinants. The paper adds to the increasing amount of literature that applies textual analysis. This body of research has grown due to the increased online availability of corporate reports and to the improvement of the analytical software tools that can be used to investigate text. We focus on the style of disclosure that characterizes banks' transparency reports, more precisely on readability of those sections of text that refer to operational risk matters. As emphasized by prior contributions, these textual attributes potentially affect the quality of disclosure and are thus likely to be of interest to investors, regulators and other relevant stakeholders.

Our sample consisted of 13 commercial banks operating in Romania in the financial year 2017. This represents $50 \%$ of all commercial banks which are active in Romania at this point in time. Only those banks which produced reports written in English were included in the sample, in order to facilitate data collection and analysis through specialized readability software. Our analysis concentrated on the readability of the narrative transparency reports, and more precisely on those disclosures dealing with operational risk management. We performed a multivariate regression analysis for the dependent variables "readability" of operational risk disclosures, whereas readability was measured by the count of Dale-Chall difficult words. We hypothesized that larger banks with better financial performance and a longer history in Romania would produce reports which are more readable.

First of all, our hypothesis regarding the positive association between age and readability is rejected. Concerning the relationship between financial performance and readability, our analysis could not confirm whether return on equity is a significant predictor of readability. Only the size, measured through total assets, was a significant predictor of the Dale-Chall number of difficult words. Results suggest that the larger the disclosing bank, the higher the number of difficult words, namely the less readable the transparency report. This might signal a disclosure manipulation strategy where the aim of the smaller banks is to improve their image and convince their stakeholders of good operational risk management, which might actually contradict the reality. The main limitation of the present study is the small sample size. A future study could carry out a comparison between Romanian banks based and other banks from around Europe. This comparison would reveal whether the struggle of banks in providing concise risk reports is the result of an ongoing learning process or management aims at manipulating stakeholders' opinions through disclosures.

\section{References}

Abu El Haija M. F., Al Hayek A. F. (2012), Operational Risk Disclosures in Jordanian Commercials Banks: It's Enough, International Research Journal of Finance and Economics 83

Anghelache, C., Manole, A., Anghel, M. G., Soare, D. V. (2016). Statistical-econometric model used to analyze the operational and insolvency risks. Theoretical and Applied Economics, 3(608), 221-228; 
Avram, K.J. and Skully, M. (2007). Australian banks' disclosure of operational risk, Monash Business Review, Vol. 3 No. 2, 1-9.

Bakar, A.S.A., Ameer, R. (2011). Readability of corporate social responsibility communication in Malaysia. Corporate Social Responsibility and Environmental Management, 18, 50-60.

Barakat A., Chernobai A., Wahrenburg M. (2014). Information asymmetry around operational risk announcements, Journal of Banking and Finance 48, 152-179

Barakat A., Khaled H. (2013), Bank governance, regulation, supervision, and risk reporting: Evidence from operational risk disclosures in European banks, International Review of Financial Analysis 30,254-273;

Benaroch M., Chernobai A., Goldstein J. (2012), An internal control perspective on the market value consequences of IT operational risk events, International Journal of Accounting Information Systems 13, 357-381

Chernobai A, Jorion P, Yu F. (2011) The determinants of operational risk in U.S. financial institutions, Journal of Financial and Quantitative Analysis 46(6),1683-725.

Cho, C.H., Roberts, R.W., Patten, D.M. (2010). The language of US corporate environmental disclosure. Accounting, Organizations \& Society 35, 431-443.

Cummins JD, Lewis CM, Wei R. (2006) The market value impact of operational loss events for U.S. banks and insurers. Journal of Banking and Finance 30(10),2605-34.

Dale, E.D., Chall, J.S. (1948), A Formula for Predicting Readability, Educational Research Bulletin, 27, 11-19;

Dănescu, T., Muntean, A. (2008). Addressing Operational Risk by Using a Risk Based Internal Audit Approach: Benefits offered to Romanian Banking System. Applied Economics, Business and Development. Retrieved from http://www.wseas.us/elibrary/conferences/2010/Tunisia/AEBD/AEBD-14.pdf ;

Dima, A. M. (2009). Operational Risk Assessment Tools for Quality Management in Banking Services. Amfiteatru Economic 11(26), 364 - 372.

Ebnöther, S., P. Vanini, A. McNeil,P. Antolinez (2003), Operational Risk: A Practicioner's View, Journal of Risk, 5.

Galloppo G., Rogora A., (2011), What has worked in operational risk?, Global Journal of Business Research, 5(3)

Gibbins M., Richardson A., Waterhouse J. (1990) The Management of Corporate Financial Disclosure: Opportunism, Ritualism, Policies, and Processes, Journal of Accounting Research, 28(1), 121-143.

Gillet R, Hübner G, Plunus S. (2010) Operational risk and reputation in the financial industry. Journal of Banking and Finance, 34(1), 224-35.

Helbok, G., \& Wagner, C. (2006), Determinants of operational risk reporting in the banking industry. The Journal of Risk, 9(1), pp. 49-74.

Hemrit W., Ben Arab M. (2011) The disclosure of operational risk in Tunisian insurance companies (2011), The Journal of Operational Risk, 6(2), 69-111

Herghiligiu, R. (2013). Operational Risk Disclosures in Romanian Commercial Banks. Journal of Public Administration, Finance and Law 4, 171-178;

Hossain, M. (2008) The Extent of Disclosure in Annual Reports of Banking Companies: The Case of India, European Journal of Scientific Research, 23(4), 659-680;

Janakiraman, U. (2008), "Operational risk management in Indian Banks in the context of Basel II: a survey of the state of preparedness and challenges in developing the framework", Asia Pacific Journal of Finance and Banking Research, 2(2), 26-44.

Leippold, M., P. Vanini (2005), The quantification of operational risk, Journal of Risk, 8.

Linsley, P.M., Shrives, P.J., Crumpton, M. (2006) Risk disclosure: an exploratory study of UK and Canadian banks, Journal of Banking Regulation, 7 (3/4), 268-82; 
Matiș, E. A. (2007). Operational Banking Risk Management - Research Performed at the Romanian Commercial Bank, Retrieved from https://core.ac.uk/download/pdf/6304098.pdf;

Mehra, Y.S. (2011), "Operational risk management in Indian Banks: impact of ownership and size on range of practices for implementation of advanced measurement approach" .

Melloni G., Caglio A., Perego P. (2017) Saying more with less? Disclosure conciseness, completeness and balance in Integrated Reports, Journal of Accounting and Public Policy, 36, 220-238.

Mocanu, M., Stanciu, V. (2015). Controlling in the Banking Industry. The Case of Romania. In Tadeusz Dudycz (Ed), The Essence and Measurement of Organizational Efficiency (221228). Springer;

Oliver, C. (1991) Strategic responses to institutional processes, Academy of Management Review, 16(1), 145-179.

Oliveira, J., Rodrigues, L.L., Craig, R. (2011) Voluntary risk reporting to enhance institutional and organizational legitimacy, Evidence from Portuguese banks. Journal of Financial Regulation and Compliance 2011, 19(3), 271-288.

Plumlee, M., Brown, D., Hayes, R.M., Marshall, R.S. (2015) Voluntary environmental disclosure quality and firm value: further evidence. Journal of Accounting and Public Policy, 34, 336361.

Power M. (2005), The invention of operational risk, Review of International Political Economy, 12:4, 577-599

Sanchez-Ballesta, J.P., Bernal Llorens (2010), M. Monitoring, reputation and accountability in issuing banks in mid-nineteenth-century Spain. Explorations in Economic History, 47(4), 403-19.

Stanciu, V. (2010). Managing Operational Risk in Banks. Analele Științifice ale Universității "Alexandru loan Cuza" din lași - Științe Economice 57, 245-260;

Socol, A., luga, I., Gavrilă-Paven, I. (2006). Procedures to manage of operational risk on the banking internal level - Romania's Case, International Academic Conference „National and Regional Economy VI", University of Herlany, Slovakia, 11-13 October 2006, 354-359;

Sturm, P. (2013). Operational and reputational risk in the European banking industry: The market reaction to operational risk events. Journal of Economic Behavior \& Organization 85, 191206.

Sundmacher, M., and Ford, G. (2006). Operational risk disclosures in financial institutions. Working Paper. URL: http://ssrn.com/abstract $=963244$.

Turlea, E., Mocanu, M., Radu, C. (2010). Corporate governance in the banking industry. Journal of Accounting and Management Information Systems 3(9), 379-402;

Turlea, E., Mocanu, M., (2016). The profile of the internal auditor in the Romanian banking sector. Audit Financiar 11(143), 1235-1245;

Wahlström, G. (2006). Worrying but accepting new measurements: the case of Swedish bankers and operational risk. Critical Perspectives on Accounting 17, 493-522;

Wang, M., Hussainey, K. (2013) Voluntary forward-looking statements driven by corporate governance and their value relevance. Journal of Accounting and Public Policy 2013, 32, 26-49. 